\title{
More patent troubles about genes
}

\section{Two decisions by the British Appeal Court raise questions about the allowable breadth of biotechnology patents, but} point to the charges patent-holders should be free to make.

As night follows day and vice versa, so the patenting of genetic information is once again an issue of public policy (see page 487), this time in the British courts. Two US biotechnology companies, Biogen and Chiron, have been challenged in the Appeal Court over the validity of the broad patent protection they have secured from the European Patent Office for the use of defined antigenic peptides in the development of vaccines against hepatitis B and the testing of blood for contamination with hepatitis $\mathrm{C}$ (previously 'non-A-non-B') respectively. The Appeal Court decided that Biogen's patent claim is too broad, but Biogen is appealing to the House of Lords, whose judicial committee is the next best thing to a supreme court in Britain. Chiron, on the other hand, has been given an injunction against the British company selling diagnostic kits for hepatitis $\mathrm{C}$ pending the full hearing of its appeal.

Reports in the general press that Chiron has been awarded the right to protect a "naturally occurring gene" are an exaggeration; only the full hearing of the Appeal Court can decide that. But both patents raise the question of how broad can be the protection for which an inventor may legitimately apply. Readers of the arcane patent literature will be familiar with the way in which inventors and/or their lawyers multiply their claims for their invention. This is the spirit in which the inventor of a mousetrap will claim that his trap will kill not onily mice, but "(2) other rodents; (3) all quadrupeds; (4) all bait-seeking animals", and so on.

These exercises in imagination appear often to be designed to tease the patent-examiners. The question that needs to be decided is how broadly, outside the scope of whatever research may have been carried out, a patent may legitimately be drawn. Another, not raised overtly in last week's court decisions, is that of the reward a patent-holder may legitimately claim from licence-holders.

Nobody dissents from the view that patents are a means by which those who have spent money on research and development are rewarded with a licence of limited term for the exploitation of their inventions. The quid pro quo for the term-monopoly is that the data on which the claims are based, including the patent itself, should be published; that ensures that the technique becomes public property once the patent has expired. Without such a system, the funds spent on research and development by private corporations would be much reduced.

So how broad may a patent legitimately be? The Chiron case is a handy illustration. The first step appears to have been the identification of an antigenically effective epitope serving as the basis for a reliable blood test. That is the product of meaningful research. On the assumption that the patent application includes (or refers to) data demonstrating the antigenic effectiveness of the particular peptide, it must then be asked what the situation would be if a patent were granted for the use of that epitope alone. Competing companies could set out to find another. Presumably, such a peptide would not be patentable; once the principle had been demonstrated that one epitope could make a blood-test (or a vaccine), it would be considered 'obvious' that a second would function similarly. But then the value of the patentmonopoly would be enormously diminished. In short, patents proved in respect of a single sub-sequence should also extend to other sub-sequences whose use in the same application is obvious. But an epitope proved effective in a bloodtest does not, on that evidence alone, make a vaccine.

The Biogen case is more difficult. Again there appears to be an epitope whose effectiveness as a vaccine has been demonstrated. These days, there should be no cavilling about the means by which the peptide is produced in bulk; Biogen could indeed consider itself cheated of protection if others could make and sell the same material by the use of a vector other than E. coli. But it is far from obvious (in the patent lawyers' sense) whether any other epitope will serve as well. The effectiveness of various epitopes in stimulating an immune response is notoriously variable. That is very much a matter of judgement, on which the House of Lords will have to pronounce.

The royalty charged for the use of patented materials is also a matter of judgement, on which the patent-holder should not be (and is not) the sole arbiter. Patent-holders are naturally inclined to expect that their income from patent royalties can be equated with some sub-multiple of their total spending on research, but much of their research will have been misguided. It is understandable that British bloodproducts organizations should be offended that Chiron plans to charge much more for its blood-testing kits than the unpatented products now on the market. It does not follow that Chiron's licensees' proposed charges are onerous nor, equally, that they are reasonable. What the patents system needs is a means of telling by arbitration whether intended royalty charges are fair. Most governments have the right to compel compulsory licences if a patent-holder fails to make patented products readily available. Excessive royalties should trigger such a finding more often than they do. 